\title{
Krajowy Program Rozwoju Ekonomii Społecznej jako dokument strategiczny. Założenia - treść - recepcja
}

\section{Krystyna Górnicka*}

\begin{abstract}
Streszczenie: Krajowy Program Rozwoju Ekonomii Społecznej został przyjęty w 2014 r. Miał stać się wyznacznikiem kierunków interwencji publicznej oraz przyczynić się do rozwoju ekonomii społecznej. Przyjęte ramy gwarantowały spójność realizowanych działań na wszystkich poziomach. W artykule omówiono proces powstawania KPRES, jego założenia, rolę regionów w jego realizacji oraz odbiór w środowisku. Jest on też próbą ustalenia, czy Program jako dokument strategiczny ma szansę wpłynąć na rozwój ekonomii społecznej. Wszystkie przewidziane w nim działania są spójne, logicznie powiązane oraz uwzględniają rolę regionów w rozwoju ES. Jednakże, na podstawie rozbieżności między nim a innymi programami (RPO) można zauważyć, iż nie wszystkie jego zapisy są wdrażane, szczególnie w regionach. O ile województwa zaktualizowały regionalne programy ES czy powołały regionalne komitety, o tyle były problemy z akredytacją OWES czy z ustaleniem liczby miejsc pracy, które mają być utworzone w PS. To pokazuje, iż KPRES prawdopodobnie nie jest postrzegany jako istotny dokument poza środowiskiem ekonomii społecznej.
\end{abstract}

Słowa kluczowe: ekonomia społeczna, program, miejsca pracy, KPRES.

\section{Wprowadzenie}

Krajowy Program Rozwoju Ekonomii Społecznej (KPRES), który został przyjęty w 2014 r., stał się wyznacznikiem kierunków interwencji publicznej. Jego celem jest nakreślenie wizji rozwoju oraz wsparcie sektora ekonomii społecznej (ES). Stworzone ramy oraz struktura miały zapewnić spójność realizacji działań oraz określić schematy planowanych przedsięwzięć. W Programie rozwój ekonomii społecznej został oparty o trzy filary: polityczny - związany z tworzeniem dobrego klimatu dla ES po stronie administracji, społeczny - dotyczący potencjału społecznego i aktywności oraz przedsiębiorczy - polegający na wzmocnieniu pozycji przedsiębiorstw społecznych na rynku [KPRES przyjęty, 2014].

Celem artykułu jest przedstawienie Krajowego Programu Rozwoju Ekonomii Społecznej jako dokumentu strategicznego, pro- gramującego zmianę na poziomie krajowym, regionalnym i lokalnym. W niniejszym artykule odpowiadam na następujące pytania: Jakie działania zaplanowano celem rozwoju sektora ES w Polsce? Jaka była intencja autorów i współautorów dokumentu oraz jak przebiegały prace redakcyjne? Czy jest to dokument wewnętrznie spójny? Czy i w jakim stopniu KPRES określa rolę regionów w rozwoju ekonomii społecznej? Z jakim odbiorem spotkał się dokument w gronie ekspertów i praktyków?

Artykuł składa się z trzech części. W pierwszej przedstawiono genezę analizowanego dokumentu, druga wskazuje jego główne założenia, strategię wdrażania oraz rolę regio-

\footnotetext{
* Krystyna Górnicka

Wydział Pedagogiki, Psychologii i Socjologii Uniwersytet Zielonogórski

al. Wojska Polskiego 69, 65-762 Zielona Góra e-mail: krysiagornicka@wp.pl
} 
nów w planowanej zmianie. W trzeciej natomiast oceniono jego znaczenie dla polityki publicznej, umiejscowienie w hierarchii ważności dokumentów oraz zaprezentowano opinie środowiska ekonomii społecznej.

\section{Geneza Krajowego Programu Rozwoju Ekonomii Społecznej}

W grudniu 2008 r. jako efekt wspólnych publiczno-społecznych uzgodnień, Zarządzeniem nr 141 Prezesa Rady Ministrów, został powołany Zespół do Spraw Rozwiązań Systemowych w Zakresie Ekonomii Społecznej (Zespół). Głównym jego zadaniem było stworzenie projektu strategii rozwoju ekonomii społecznej. Wypracowane założenia zostały oficjalnie zaprezentowane na III Ogólnopolskich Targach Aktywnych Form Pomocy w Byczynie w czerwcu 2012 r., po czym poddane konsultacjom społecznym [KPRES, 2014]. W ich trakcie Zarząd Kujawsko-Pomorskiej Federacji Organizacji Pozarządowych zasugerował, iż Program w takiej formie nie może być wdrażany. Zarzucił on autorom KPRES nakładanie sztywnych ram na sektor, co zaszkodzi kreatywności i reagowaniu na zmiany oraz nowe i aktualne wyzwania [Kaczorek, 2012]. Stanowisko zaprezentowane przez Kujawsko-Pomorską Federację Organizacji Pozarządowych zostało poparte przez Dolnośląską Federację Organizacji Pozarządowych [Weihs, 2012].

Raport z przeprowadzonych konsultacji wskazuje na udział 111 podmiotów, w większości jednostek administracji publicznej. Głos w sprawie zabrali też przedstawiciele ośrodków wsparcia ekonomii społecznej, podmiotów ekonomii społecznej, organizacji pozarządowych, a także osoby fizyczne. Zdaniem autorów raportu Program został pozytywnie odebrany i oceniony przez środowisko, jednak mimo to wymagał dopracowania. Najwięcej uwag o charakterze negatywnym dotyczyło diagnozy oraz sposobu sformułowania celów KPRES. Zasugerowano, iż dia- gnoza nie oddaje pełnego obrazu ekonomii społecznej, źle dobrane zostały zadania, natomiast dane dotyczące przykładowo spółdzielni socjalnych są zbyt ogólne i głównie ilościowe. W konsekwencji nie prowadzi to do pokazania ich rzetelnego obrazu [Cibor, 2012]. Podczas VI Ogólnopolskich Spotkań Ekonomii Społecznej w październiku 2012 r. również dyskutowano nad projektem Programu. W czasie konferencji kilku panelistów ostro skrytykowało niektóre jego zapisy [Cibor, 2013]. Raport z konsultacji, który okazał się ważny w dyskusji o Programie oraz projekt KPRES zostały zaprezentowane w październiku 2012 r. na posiedzeniu Zespołu.

W lutym 2013 r. w czasie seminarium zorganizowanego przez Instytut Spraw Publicznych w imieniu Stałej Konferencji Ekonomii Społecznej także dyskutowano o założeniach KPRES. W odniesieniu do prezentacji Cezarego Miżejewskiego głos zabrali m.in. Joanna Wardzińska z Towarzystwa Inwestycji Społeczno-Ekonomicznych, Tomasz Schimanek z Instytutu Spraw Publicznych, Krzysztof Herbst z Fundacji Inicjatyw Społeczno-Ekonomicznych. Tomasz Schimanek poruszył problem zbyt dużej roli Państwa w programie: „Punkt ciężkości jest przechylony w stronę podejścia, że ekonomia społeczna jest instrumentem realizacji polityk publicznych. Wolałbym rozumienie ekonomii społecznej jako jedną z form aktywności obywateli. Zgadzam się, że jest to przeregulowane i momentami za dużo jest państwa" [Muzińska, 2013]. Jednakże trudno sobie wyobrazić program rozwoju jako programowanie polityki publicznej bez wskazania, jaką rolę widzi władza publiczna dla organizacji obywatelskich i jakie instrumenty w tym względzie projektuje.

Krzysztof Herbst zarzucił odejście od podstaw ekonomii społecznej oraz przerzucenie zadań publicznych w dużej mierze na PES za pomocą licznych instrumentów: „Ten dokument zaczyna się od opowieści o rozmaitych strategiach polskich i europejskich i z całą dobrą wolą próbuje to wdrożyć. Jeżeli tak się 
tworzy dokumenty, że gdzieś na górze jest jakaś racja wyższa, to piszemy go w trybie zadaniowym. (...) Mamy używać do tego np. takiego instrumentu jak społecznie odpowiedzialne zamówienia publiczne. Zapominamy jednak, że system zamówień publicznych został wymyślony w zupełnie innym celu nakręcania gospodarki, a nie po to, by czynić dobro" [ibidem]. Mimo zastrzeżeń i negatywnych komentarzy, uczestnicy seminarium zauważyli, że nowa propozycja KPRES jest lepsza od poprzedniej.

Zgodnie z wymaganiami ustawy z dnia 6 grudnia 2006 r. o zasadach prowadzenia polityki rozwoju KPRES został poddany ewaluacji ex ante. W raporcie $z$ ewaluacji podkreślono, iż celem Programu jest spowodowanie zmiany społecznej. Przenikanie się rezultatów spowoduje efekt synergii, zaś podejście strategiczne jest odpowiedzią na problemy i potrzeby sektora. Rekomendacje, które zawarto $\mathrm{w}$ raporcie zostały uwzględnione $\mathrm{w}$ treści Programu [KPRES, 2014, s. 7]. Kolejna wersja KPRES została opracowana w 2013 r. na podstawie wniosków z konsultacji społecznych, które przeprowadzono w 2012 r. oraz ewaluacji ex ante. W porównaniu do poprzedniej poszerzono diagnozę, wprowadzono aktualne dane, uzupełniono Program o listę wskaźników, plan finansowy, a także uporządkowano cele i zadania, którym przyporządkowano terminarz, źródła finansowania i koordynatorów. W poprawionej wersji KPRES założono, iż podjęte w Programie działania przyczynią się do powstania ponad 38 tys. miejsc pracy [Nowa, 2014] (ok. 35 tys. będzie miało trwały charakter, natomiast ok. 20 tys. finansowanych będzie ze środków EFS [KPRES, 2014]).

30 kwietnia 2014 r. projekt Krajowego Programu Rozwoju Ekonomii Społecznej został zaakceptowany przez Komisję Wspólną Rządu i Samorządu Terytorialnego. Następ- nie został przekazany do Ministerstwa Infrastruktury i Rozwoju w celu sprawdzenia jego zgodności ze Strategią Rozwoju Kraju 2020 [Krajowy, 2014]. Pod koniec czerwca 2014 r. projekt Krajowego Programu Rozwoju Ekonomii Społecznej przekazano do Kancelarii Prezesa Rady Ministrów w celu skierowania go pod obrady Komitetu Stałego Rady Ministrów [MPiPS, 2014]. 12 sierpnia 2014 r. KPRES został przyjęty przez Radę Ministrów. Za główny cel Programu uznano doprowadzenie do tego, by ekonomia społeczna stała się istotnym czynnikiem wzrostu zatrudniania, spójności oraz rozwoju społecznego. Twórcy Programu zauważyli również, iż niezwykle ważne jest zwiększenie udziału PES w realizacji usług społecznych na poziomie lokalnym w celu wzmocnienia zarówno podmiotów, jak i samej wspólnoty [KPRES przyjęty, 2014].

\section{Cele, założenia i strategia wdrażania}

Autorzy KPRES zdefiniowali cel nadrzędny Programu następująco: W roku 2020 ekonomia społeczna stanowi ważny czynnik wzrostu zatrudnienia, spójności społecznej oraz rozwoju kapitału społecznego [KPRES, 2014, s. 26]. Ustalono, że do osiągnięcia tak określonego celu potrzebne będzie zwiększenie działań na rzecz całego sektora ekonomii społecznej, a także zwiększenie wsparcia kierowanego do niego. Jak wskazano w KPRES, nacisk należy położyć na osoby i podmioty zaangażowane w ekonomię społeczną, przedsiębiorstwa społeczne jak również tworzenie miejsc pracy dla osób w trudnej sytuacji społecznej, dostarczenie dobrej jakości usług społecznych oraz stworzenie stabilnych podstaw działalności przedsiębiorstw społecznych [ibidem, s. 26]. Poniżej zaprezentowano strukturę celu nadrzędnego oraz celów głównych i operacyjnych. 


\section{Rysunek 1. Schemat Krajowego Programu Rozwoju Ekonomii Społecznej}

Cel nadrzędny: W roku 2020 ekonomia społeczna stanowi ważny czynnik wzrostu zatrudnienia, spójności społecznej oraz rozwoju kapitału społecznego

Cel główny: Do roku 2020 podmioty ekonomii społecznej staną się ważnym elementem aktywizacji osób w trudnej sytuacji oraz dostarczycielem usług użyteczności publicznej działającym we wspólnotach samorządowym

Cel operacyjny 1: Wspólnota

Wzmocnienie roli podmiotów ekonomii społecznej we wspólnotach samorządowych
Cel operacyjny 2: Otoczenie

Powstanie i utrzymanie 35 tys. miejsc pracy w przedsiębiorstwach społecznych

Źródło: [KPRES, 2014, s. 27].

Realizacja celu nadrzędnego oraz całego Programu została oparta o 5 priorytetów, które obejmują 19 kierunków interwencji. Cel operacyjny 1: Odpowiedzialna wspólnota realizowany będzie poprzez Priorytet I Ekonomia społeczna na społecznie odpowiedzialnym terytorium, III System wsparcia ekonomii społecznej oraz V Edukacja dla ekonomii społecznej. W Priorytecie I szczególny nacisk, w części merytorycznej, został położony na realizację usług prozatrudnieniowych oraz usług użyteczności publicznej. Priorytet III skupia się na wymaganych uwarunkowaniach do tworzenia sieci współpracy oraz animacji lokalnej, zaś Priorytet V wskazuje rolę edukacji w rozwoju odpowiedzialnej wspólnoty [ibidem, s. 33]. W ramach Priorytetu II Działania regulacyjne w zakresie ekonomii społecznej i III System wsparcia ekonomii społecznej realizowany będzie Cel operacyjny 2 Otoczenie. Działania i instrumenty przewidziane w powyższych Priorytetach mają wspomóc tworzenie przyjaznego otoczenia prawnego, finansowego oraz organizacyjnego, a tym samym stworzyć infrastrukturę do rozwoju ekonomii społecznej. W Priorytecie I zostały określone konkretne preferencje, które mają służyć zrealizowaniu Celu 2 [ibidem]. Realiza-
Cel operacyjny 3: Przywództwo

Wzrost skuteczności mechanizmów zarządzania i koordynacji polityki ekonomii społecznej
Cel operacyjny 4: Kompetencje

Wzrost kompetencji w obszarze ekonomii społecznej w społeczeństwie

cja Celu Operacyjnego 3 Przywództwo będzie opierała się o środki, mechanizmy i rozwiązania systemowe przewidziane w Priorytecie IV Włączenie ekonomii społecznej do głównego nurtu polityk publicznych na poziomie krajowym i regionalnym, III System wsparcia ekonomii społecznej oraz V Edukacja dla ekonomii społecznej. Interwencje w tych Priorytetach związane są z koordynacją działań podejmowanych na poziomie krajowym i regionalnym, włączeniem ekonomii społecznej do głównego nurtu polityk publicznych, sieciowaniem oraz zwiększaniem wiedzy i kompetencji z zakresu gospodarki społecznej. Priorytet V Edukacja dla ekonomii społecznej, obejmujący kwestie edukacyjne i świadomościowe na rzecz ekonomii społecznej, przyczyni się również do realizacji założeń Celu operacyjnego 4 Kompetencje [ibidem].

Wdrożenie powyższych działań wymaga skoordynowania ich w zakresie organizacyjnym, finansowanym czy prawnym. Zaangażowanie administracji publicznej i wielu partnerów publiczno-społecznych ${ }^{1}$ niesie ryzyko

Zgodnie z zapisami KPRES zaplanowano, iż w realizację Programu zaangażowane będą m.in.: Urząd Zamówień Publicznych, Urząd Ochrony Konkurencji i Konsumentów, minister właściwy ds. zabezpieczenia społecznego, jednostki samorządu terytorialnego wszystkich szczebli. 
powielania działań, co w konsekwencji może doprowadzić do większego wsparcia jednych obszarów kosztem innych. Dlatego niezwykle istotne jest powiązanie wszystkich działań - zarówno tych na poziomie krajowym, jak i regionalnym. Zarządzanie całym Programem zostało powierzone Krajowemu Komitetowi Rozwoju Ekonomii Społecznej (KKRES)², który określa kierunki interwencji. Do działań na poziomie kraju należą szczególnie te o charakterze legislacyjnym oraz organizacyjnym. Finansowane są one ze środków budżetowych. Zgodnie z założeniami Programu, KKRES powinien być głównym koordynatorem prac dotyczących Programu, a w jego skład mają wchodzić przedstawiciele resortów z kluczowych dla ekonomii społecznej obszarów, reprezentanci województw oraz przedstawiciele sektora. Środki na publikacje i ekspertyzy pochodzą z budżetu ministra właściwego do spraw zabezpieczenia społecznego oraz Europejskiego Funduszu Społecznego [ibidem, s. 70]. Wsparciem dla KKRES jest Krajowy Sekretariat Ekonomii Społecznej, którego funkcję, zgodnie z Regulaminem Komitetu, pełni Departament Ekonomii Społecznej i Pożytku Publicznego w Ministerstwie Rodziny, Pracy i Polityki Społecznej. Do jego zadań, zgodnie z KPRES, należy koordynowanie prac związanych z działaniami administracji publicznej w obszarze ekonomii społecznej, organizacja procesu akredytacji OWES, działania edukacyjne, promocyjne, a także wsparcie doradcze dla województw. Zajmuje się on również monitoringiem wdrażania Programu na poziomie regionów oraz ewaluacją [ibidem]. Zgodnie z zapisami KPRES powstał „fundusz funduszy". Jego rolę pełni obecnie Krajowy Fundusz Przedsiębiorczości Społecznej. Wybrani przez Bank Gospodarstwa Krajowego pośrednicy finansowi: Fundusz Regionu Wałbrzyskiego i Towarzystwo Inwestycji Spo-

KKRES został powołany Zarządzeniem nr 7 Ministra Pracy i Polityki Społecznej z dnia 27 lutego 2017 r. w sprawie powołania Krajowego Komitetu Rozwoju Ekonomii Społecznej.
łeczno-Ekonomicznych S.A będą udzielać pożyczek podmiotom ekonomii społecznej. Zaplanowano, iż wsparcie pochodzące z pożyczek i poręczeń będzie stanowiło uzupełnienie dotacji przyznawanych w ramach Regionalnych Programów Operacyjnych (RPO) na miejsca pracy w przedsiębiorstwach społecznych [MRPiPS, 2016].

Najważniejsze działania w obszarze ekonomii społecznej będą jednak realizowane na poziomie województw. Dlatego niezwykle istotne są interwencje wskazane w Priorytecie I i II, które będą wpisywały się w regionalne polityki rozwoju. Finansowanie tych działań pochodzi ze środków Funduszu Pracy, Państwowego Funduszu Rehabilitacji Osób Niepełnosprawnych oraz jednostek samorządu terytorialnego. Ich rozdysponowaniem zajmą się Ośrodki Pomocy Społecznej, Powiatowe Centra Pomocy Rodzinie czy Powiatowe Urzędy Pracy. Dodatkowym źródłem funduszy będą te pochodzące $z$ Regionalnych Programów Operacyjnych [KPRES, 2014, s. 71]. Środki unijne w ramach Europejskiego Funduszu Społecznego (EFS) będą w większości przeznaczone na wspieranie działań systemu Ośrodków Wsparcia Ekonomii Społecznej oraz koordynację ekonomii społecznej na poziomie województw, która została przekazana Regionalnym Ośrodkom Polityki Społecznej. To one będą zarządzały wdrażaniem Programu na poziomie poszczególnych województw. Wspierane będą również, ze środków krajowych, fundusze pożyczkowe, działania innowacyjne czy też edukacyjne, zaś ze środków regionalnych start-upy dla młodych organizacji obywatelskich w ramach Funduszu Inicjatyw Obywatelskich [ibidem].

\section{Miejsce regionów w Programie ${ }^{3}$}

W Programie zwrócono uwagę, iż rozwój sektora ekonomii społecznej powinien

\footnotetext{
3 Na poziomie województwa szczególny wpływ na rozwój ekonomii społecznej mają: Regionalny Ośrodek Polityki
} 
opierać się na działaniach w społecznościach lokalnych: „(...) Rozwój sektora ekonomii społecznej powinien opierać się na działaniach zakorzenionych w społeczności lokalnej, orientacji na kwestie społeczne, preferencjach związanych z aktywnością lokalną i lokalnym rynkiem wewnętrznym. Oznacza to, że produkty i usługi oferowane przez przedsiębiorstwa społeczne i podmioty ekonomii społecznej muszą odpowiadać potrzebom odbiorców we wspólnocie lokalnej. Działanie to może i powinno być zbieżne z konstytucyjnymi obowiązkami wspólnoty samorządowej, których celem jest bieżące i nieprzerwane zaspokajanie zbiorowych potrzeb ludności w drodze świadczenia powszechnie dostępnych usług użyteczności publicznej (...)" [ibidem, s. 34].

Jak pokazuje przytoczony cytat, działania powinny odpowiadać na specyficzne potrzeby i problemy społeczności lokalnych. Należy je oprzeć na wzajemnych relacjach obywateli, instytucji czy innych podmiotów pochodzących z jednej wspólnoty samorządowej. W Programie zaplanowano przedsięwzięcia, które powinny zostać zrealizowane na poziomie regionów. Jednakże planowanie zostało przeprowadzone odgórnie, na poziomie ogólnym w Programie. Powoduje to sytuację, w której każde z województw będzie musiało przełożyć i dostosować działania do specyfiki i potrzeb swojego regionu.

Niezwykle istotne z punktu widzenia wdrażania założeń KPRES na poziomie regionów są diagnozy lokalne z uwzględnieniem procesów rozwojowych. Powiązane jest to z ciągłą weryfikacją danych oraz z czynnym udziałem społeczności lokalnej w tworzeniu diagnoz. W związku z tym planuje się,

Społecznej jako koordynator działań administracji publicznej w obszarze ekonomii społecznej, Instytucja Zarządzająca Regionalnym Programem Operacyjnym jako dysponent środków unijnych, Regionalny Komitet Rozwoju Ekonomii Społecznej jako koordynator działań województwa w obszarze ES oraz Ośrodki Wsparcia Ekonomii Społecznej - realizatorzy działań związanych z ekonomią społeczną w ramach projektów finansowanych z EFS. w Działaniu związanym ze wspieraniem partycypacyjnych modeli badania, wprowadzenie zmian prawnych, które pozwolą uporządkować programowanie strategiczne na poziomie samorządu lokalnego, zwłaszcza w obszarze polityki społecznej, a także system konsultacji społecznych. Zaplanowano do realizacji m.in. przegląd aktów prawnych, wprowadzenie obowiązku przygotowywania jednolitej strategii polityki społecznej gminy czy wprowadzenie jednolitych trzyletnich programów polityki społecznej [ibidem].

Kolejnym działaniem silnie powiązanym z poziomem lokalnym jest Działanie I.2 związane ze wsparciem aktywności obywatelskiej i samoorganizacji. Rozwój ekonomii społecznej na poziomie lokalnym nie jest możliwy bez rozwoju inicjatyw i organizacji obywatelskich. W związku z tym, planuje się zmiany prawne w obszarze aktywności obywatelskiej, które mają na celu ułatwienie zrzeszania się, wspieranie rozwoju instytucjonalnego oraz nowopowstałych organizacji, wspieranie działań sieciujących lub promujących dialog, a także wsparcie dla rozwoju jednostek pomocniczych gminy i wolontariatu [ibidem, s. 35-36].

Wsparcie dla rozwoju usług użyteczności publicznej przez ekonomię społeczną zaplanowano w Działaniu I.3. Jak zauważyli autorzy KPRES: „(...) Wzajemne relacje sektora ekonomii społecznej z samorządem gminnym i powiatowym wymagają zintegrowanych działań na rzecz aktywnego włączenia się partnerów $\mathrm{w}$ realizację lokalnych usług użyteczności publicznej. W debacie europejskiej wskazuje się w szczególności na rozwój usług uzupełniających i wspierających rolę i funkcje rodziny, w tym: opieki nad dziećmi, usług w zakresie opieki nad osobami starszymi i niesamodzielnymi oraz osobami niepełnosprawnymi (...)" [ibidem, s. 36-37].

W związku z powyższym w Programie wskazano działania o charakterze [ibidem, s. 37-38]: 
- metodycznym (wypracowanie standardów dla różnych typów usług, wdrażanie projektów innowacyjnych testujących, bazy dobrych praktyk na poziomie regionalnym),

- $\quad$ systemowym (powołanie Ogólnopolskiej Platformy Usług Społecznych jako partnerstwa publiczno-społecznego z udziałem przedstawicieli MPiPS, zrzeszeń jednostek samorządu terytorialnego oraz federacji organizacji obywatelskich zrzeszających organizacje realizujące usługi społeczne),

- prawno - edukacyjnym (zmiany prawne przy zlecaniu zadań użyteczności publicznej i rozliczenia ich realizacji, przygotowanie i wdrożenie w lokalnych dokumentach zapisów dotyczących stosowania klauzul społecznych w zamówieniach publicznych, wprowadzenie instytucji kontraktu terytorialnego, zawieranego przez samorząd wojewódzki z samorządami gminnymi i powiatowymi, działania edukacyjne),

- rozwojowym (wypracowanie ścieżek finansowania ze środków europejskich projektów realizowanych wspólnie przez gminy lub powiaty i organizacje obywatelskie).

Niezwykle istotnym kierunkiem rozwoju ekonomii społecznej są działania związane z programami rozwojowymi, szczególnie na poziomie regionalnym i lokalnym. Dlatego planuje się wspieranie zrównoważonego rozwoju (rozwój podmiotów ekonomii społecznej związanych z ekologią, przedsiębiorstw społecznych w zakresie selektywnego zbierania odpadów, wsparcie dla rolnictwa społecznego), rozwoju społeczności lokalnej, tożsamości i edukacji kulturowej (miejsca pracy w PES związanych z obszarem turystyki społecznej, budownictwem społecznym czy animacją społeczną), solidarności pokoleń (zakładanie PES przez osoby w wieku przedemerytalnym, rozwój podmiotów wspierających politykę rodzinną, wsparcie dla PES ofe- rujących usługi starszym konsumentom) oraz rozwoju usług aktywnej integracji (zmiany w przepisach związanych z zatrudnieniem socjalnym, kształcenie pracowników instytucji pomocy i integracji społecznej w zakresie ekonomii społecznej i przedsiębiorczości społecznej, system zatrudnienia monitorowanego) [ibidem, s. 39-40].

Potrzeba zapewnienia ciągłego wsparcia doradczego, szkoleniowego oraz animacyjnego na każdym szczeblu wynika z zapotrzebowania środowiska ekonomii społecznej. Pakiet takich usług (świadczonych łącznie), w skład którego wchodzą: usługi animacji lokalnej, usługi rozwoju ekonomii społecznej, usługi wsparcia istniejących przedsiębiorstw społecznych świadczony jest przez ośrodki wsparcia ekonomii społecznej (konsorcjum lub partnerstwo kilku instytucji) [ibidem, s. 50]. Finansowanie ośrodków odbywa się w ramach Regionalnych Programów Operacyjnych poszczególnych województw.

Szczególna rola regionów w polityce rozwoju powoduje potrzebę włączenia ekonomii społecznej do działań realizowanych na poziomie województwa. To na tym szczeblu zapadają kluczowe dla polityk lokalnych decyzje programowe, organizacyjne czy finansowe. W związku z tym w ramach Działania IV.2 związanego z koordynacją zaplanowano m.in. następujące zadania: włączenie ekonomii społecznej do strategii rozwoju każdego województwa, realizacja i monitoring regionalnych programów rozwoju ekonomii społecznej, stworzenie Regionalnych Komitetów Rozwoju Ekonomii Społecznej z funkcją koordynacji działania województw w zakresie ekonomii społecznej oraz ustanowienie Regionalnego Ośrodka Polityki Społecznej (ROPS) jako odpowiedzialnego za koordynowanie działania władzy publicznej w zakresie realizacji regionalnego programu. Zgodnie z KPRES, ROPS powinien również określać kierunki, preferencje i procedury wsparcia w obszarze ekonomii społecznej w ramach Regionalnych Programów Opera- 
cyjnych [ibidem, s. 55-56]. Zapisy Programu dotyczące koordynacji przez ROPS zostały odzwierciedlone w Wytycznych w zakresie realizacji przedsięwzięć $w$ obszarze włączenia społecznego i zwalczania ubóstwa z wykorzystaniem środków Europejskiego Funduszu Społecznego i Europejskiego Funduszu Rozwoju Regionalnego na lata 20142020. Umożliwiło to finansowanie większości działań przypisanych w Programie Regionalnym Ośrodkom Polityki Społecznej w ramach projektów realizowanych ze środków EFS. Przykładem może być projekt „Efekt Synergii - koordynacja lubuskiej ekonomii społecznej" realizowany przez ROPS województwa lubuskiego. Celem projektu jest poprawa warunków rozwoju PES, a także wzmocnienie potencjału instytucji otoczenia sektora ekonomii społecznej ${ }^{4}$.

Nowa rola ROPS-ów w systemie wsparcia ekonomii społecznej wiąże się jednak z licznymi wyzwaniami, m.in. dostosowaniem się, w przypadku realizowanych projektów, do sztywnych ram, jakie nakładają Wytyczne czy też próbą uspójnienia działań koordynacyjnych na poziomie regionalnym z tymi realizowanymi na poziomie centralnym.

Ekonomia społeczna jest jeszcze zjawiskiem słabo zakorzenionym na poziomie lokalnym i regionalnym oraz często łączonym z pomocą społeczną. Dlatego Działania w Priorytecie V skupione są na jej upowszechnianiu oraz budowaniu pozytywnej marki, a także na zwiększaniu kompetencji osób zaangażowanych w jej rozwój. Działanie V.1 związane z tożsamością kulturową ma na celu stworzenie programów o ekonomii społecznej dla edukacji pozaformalnej [ibidem, s. 60]. W Działaniu V.2 dotyczącym edukacji dla środowiska lokalnego wsparcie edukacyjne w postaci szkoleń, doradztwa czy animacji ma być kierowane do członków Powiatowych i Wojewódzkich Rad Zatrudnie-

4 Efekt Synergii - koordynacja lubuskiej ekonomii społecznej, www.es.lubuskie.pl. nia, Gminnych, Powiatowych i Wojewódzkich Rad Działalności Pożytku Publicznego, wójtów, burmistrzów, prezydentów miast i starostów, członków kierownictwa jednostek pomocniczych gminy oraz członków komisji polityki społecznej i rozwoju gospodarczego w gminach, powiatach i województwach [ibidem, s. 60-61]. Celem tak zaplanowanej interwencji jest wzrost wiedzy władz lokalnych, co w konsekwencji powinno zmienić postrzeganie ekonomii społecznej na poziomie lokalnym i regionalnym. Planowane są też działania edukacyjne skierowane do osób na poziomie szkolnym i akademickim, mające dostarczyć wiedzy i kompetencji związanych z przedsiębiorczością społeczną oraz pozaformalna edukacja dzieci i młodzieży. Działania w tym zakresie zostaną oparte o Regionalne Fundusze Młodzieżowe, które będą promowały młodzieżowe inicjatywy lokalne na poziomie lokalnym, regionalnym i krajowym [ibidem, s. 63].

\section{Recepcja Programu i jego perspektywy}

Krajowy Program Rozwoju Ekonomii Społecznej stał się punktem odniesienia dla całego programowania interwencji w obszarze ekonomii społecznej. Obligowało to do określenia ram funkcjonowania tego sektora w przestrzeni publicznej. W środowisku opinie na temat Programu były zróżnicowane. Piotr Frączak na łamach portalu ekonomiaspoleczna.pl zwraca uwagę, iż zaproponowany w KPRES sposób koordynowania ekonomii społecznej na poziomie regionalnym nie jest pomysłem trafionym. Jednakże należy to rozwiązanie wykorzystywać. Porusza także kwestię braku dokumentu strategicznego nakierowanego na organizacje pozarządowe i tego, iż KPRES jest tym, który obecnie obejmuje sektor pozarządowy i tworzy z niego zaplecze do rozwoju ekonomii społecznej [Frączak, 2014]. 
Problematyce związanej z miejscami pracy w ekonomii społecznej została poświęcona jedna sesja tematyczna na VIII Ogólnopolskich Spotkaniach Ekonomii Społecznej. Paweł Chorąży z Ministerstwa Rozwoju dostrzegł szansę realizacji założeń Programu w 17 programach wydatkowania środków EFS na lata 2014-2020 (jednego krajowego i 16 regionalnych). Jak zauważył: „W każdym programie jest tzw. priorytet inwestycyjny, czyli szufladka, która mówi o wspieraniu przedsiębiorstw społecznych i ekonomii społecznej. Chodzi jednak o danie impulsu do stworzenia miejsc pracy" [Cabajewski, 2014].

Do kwestii miejsc pracy w KPRES odniósł się również były wicemarszałek województwa lubuskiego Maciej Szykuła, który omawiał rolę samorządów regionalnych $\mathrm{w}$ rozwoju ekonomii społecznej. Podkreślił, iż 700 osób do zatrudnienia $w$ lubuskim to minimum, a istotne jest, aby wykorzystać szansę, którą stworzył KPRES i fundusze EFS [Cabajewski, 2014].

Magda Dobranowska-Wittels na łamach portalu ekonomiaspoleczna.pl zwróciła uwagę na to, iż przyjęcie KPRES przyczyniło się do otrzymania środków z UE na ekonomię społeczną w kwocie ponad 1 mld PLN ${ }^{5}$, mimo źle ocenionego przez Komisję Europejską wykorzystywania środków europejskich w latach 2007-2013. W swoim artykule zauważa, iż niestety regiony, które odpowiadają za dystrybucję środków UE oraz realizację wskaźników zarówno na poziomie RPO, jak i KPRES, nie mają spójnych regionalnych programów operacyjnych w obszarze związanym z ES z zapisami Programu Operacyjnego Wiedza Edukacja Rozwój, jak i z Krajowym Programem Rozwoju Ekonomii Społecznej [Dobranowska-Wittels, 2015]. Pokazuje to, iż

\footnotetext{
Przyjęcie KPRES było jednym z warunków ex-ante w perspektywie finansowej na lata 2014-2020. Oznacza to, iż uruchomienie funduszy objętych Wspólnymi Ramami Strategicznymi 2014-2020 uzależnione zostało od spełnienia warunków wstępnych, które miały przyczynić się do efektywnej realizacji programów.
}

zapisy KPRES nie zostały zastosowane przez samorządy wojewódzkie w trakcie tworzenia regionalnych programów operacyjnych. Szczególnym problemem jest niespójność związana z miejscami pracy występująca na poziomie RPO a KPRES. Magda Dobranowska-Wittels przytacza uwagi zgłaszane przez przedstawicieli OWES, przywołując przykład województwa lubelskiego, w którym to ze środków EFS powinno powstać wg KPRES 1.260 miejsc pracy, a w RPO zaplanowano tylko 302. Sytuacja ta dotyczy większości województw, gdzie zapisy Programu nie został odzwierciedlone w Regionalnych Programach Operacyjnych, a tym samym wprowadzono chaos, gdyż, jak zauważył przedstawiciel OWES, nie wiadomo, do których wartości należy się stosować.

Waga KPRES w stosunku do innych dokumentów została wyjaśniona na VIII Ogólnopolskich Spotkaniach Ekonomii Społecznej przez Piotra Krasuskiego z Ministerstwa Rozwoju: „Komisja Europejska negatywnie oceniła system wspierania ekonomii społecznej w Polsce w poprzednim okresie programowania. Zdaniem KE był on zbyt drogi i nieefektywny, to znaczy nie prowadził do osiągnięcia celów, które zakłada EFS, czyli zwiększenia liczby miejsc pracy. Dlatego wiosną, podczas negocjacji umowy partnerstwa, Polska usłyszała od KE twarde "nie”, jeśli chodzi o wspieranie ekonomii społecznej. Uratowało nas to, że rząd właśnie przyjął KPRES, w którym przewidziane było stworzenie znacznie większej liczby miejsc pracy, a także akredytacja OWES-ów i podejście popytowe, czyli świadczenie usług odpowiadających na realne potrzeby podmiotów ekonomii społecznej. Jeśli jednak Komisja zobaczy, że KPRES nie jest realizowany, będzie chciała wpływać na zmianę Programów (..)" [Dobranowska-Wittels, 2015].

Powyższy cytat wskazuje KPRES jako znaczący dokument, który może zdecydować o budowie potencjału sektora w kolejnych latach. Pokazuje także, iż mimo tego, 
że samorządy nie zastosowały zapisów Programu w trakcie tworzenia RPO, powinny się do nich stosować.

\section{Podsumowanie}

Krajowy Program Rozwoju Ekonomii Społecznej poprzez założenia, na których został oparty miał stać się czynnikiem zmiany w działaniach sektora oraz ramami strategicznymi jego rozwoju. Proces tworzenia dokumentu był stosunkowo długi, jednakże starano się w jego trakcie uwzględnić stanowiska i uwagi różnych stron. Najwięcej głosów sprzeciwu i niezadowolenia pojawiło się w trakcie powstawania i konsultacji Programu. Część organizacji zwracała uwagę, iż w proponowanych formułach Program nie powinien zostać przyjęty. Szeroko prowadzona akcja konsultacyjna oraz otwartość na zmiany i uwagi wśród autorów KPRES doprowadziły do przyjęcia przez rząd w 2014 r. poprawionej wersji Programu. Najważniejszym celem Programu stało się uczynienie z ekonomii społecznej czynnika wzrostu zatrudnienia i rozwoju kapitału społecznego. Realizacja celu głównego została oparta na 5 priorytetach i aż 19 kierunkach interwencji. Każdemu Działaniu został przyporządkowany koordynator oraz orientacyjne źródła finansowania wraz z harmonogramem realizacji. Zaproponowana przez autorów struktura Programu wydaje się być spójna oraz logicznie połączona. Jednakże, mimo iż dokument funkcjonuje już 3 lata ciągle występują związane z nim nieścisłości. Szczególnie dyskutowane są kwestie związane z miejscami pracy i rozbieżnością zapisów, która powstała na linii KPRES a RPO. W większości województw nie uwzględniono zapisów KPRES związanych z liczbą tworzonych miejsc pracy. Sytuacja ta jest o tyle istotna, iż samo przyjęcie Programu przyczyniło się do otrzymania dużych środków na działania wspierające ekonomię społeczną. Pokazuje to, że zapisy Programu nie współgrają z sytuacją regionów lub na etapie tworzenia regionalnych programów operacyjnych nie potraktowano KPRES jako dokumentu, który stwarza ramy rozwoju ekonomii społecznej. W przypadku tej pierwszej opcji może wydawać się to dziwne, gdyż zapisy KPRES nadają istotną rolą w rozwoju ekonomii społecznej właśnie regionom. Należy jednak pamiętać, iż Program został stworzony przez grono ekspertów na poziomie krajowym i miał być dostosowany do potrzeb regionalnych na podstawie Regionalnych Programów Rozwoju Ekonomii Społecznej. Problem ten może również wynikać ze słabości instytucji programujących politykę społeczną lub braku ich siły przebicia. Możliwe, że właśnie w tym miejscu należy szukać przyczyn rozbieżności. Tak więc w KPRES uwzględniona jest istotna rola regionów $w$ rozwoju ekonomii społecznej. Jednakże są to odgórne ramy, w które każdy region powinien się wpisać, nie zaś uwzględnienie złożoności i różnorodności każdego z nich.

Działania wskazane w Programie zostały tak opisane, aby realizowane w ich ramach przedsięwzięcia przełożyły się na rozwój sektora ES w Polsce. Widać jednak na podstawie rozbieżności między różnymi Programami, iż prawdopodobnie zapisy KPRES nie są konsekwentnie wdrażane, szczególnie w regionach. O ile województwa zaktualizowały regionalne programy ekonomii społecznej czy powołały regionalne komitety rozwoju ekonomii społecznej, o tyle były problemy z akredytacją OWES (cofnięta akredytacja dla wszystkich ośrodków) oraz z ustaleniem liczby miejsc pracy, które mają być utworzone w PS. W 2017 r. zaplanowano aktualizację KPRES. Wynika ona z potrzeby dostosowania Programu do Strategii Odpowiedzialnego Rozwoju oraz uporządkowania kwestii monitoringowych i finansowych. Zbiegnie się to z przygotowywanymi zmianami w Regionalnych Programach Operacyjnych, które mają być renegocjowane z Komisją Europejską. Po wprowadzeniu zmian w tych dokumentach będzie można zaobserwować, czy KPRES 
rzeczywiście jest traktowany jak wyznacznik założeń rozwoju ekonomii społecznej, w tym szczególnie w regionach oraz czy stał się

\section{Literatura}

Cabajewski S. (2014). 35 tysięcy nowych miejsc pracy $w$ przedsiębiorstwach społecznych - kto za to odpowiada?, http://www.ekonomiaspoleczna.pl/wiadomosc/1028752.html (dostęp: 02.04.2017).

Cibor K. (2012). Raport z wstępnych konsultacji Krajowego Programu Rozwoju ES, http://www.ekonomiaspoleczna.pl/wiadomosc/807270.html (dostęp: 02.04.2017).

Cibor K. (2013). Krajowy Program Rozwoju Ekonomii Społecznej - zobacz, jak się zmienia, http://www.ekonomiaspoleczna.pl/x/655566?doc_id=838301\&projekt=433510 (dostęp: 02.04.2017).

Dobranowska-Wittels M. (2015). Bez rozmów ambitne cele ekonomii społecznej trudne do osiagnięcia, http://wiadomosci.ngo.pl/wiadomosc/1887571. html (dostęp: 22.04.0217).

Frączak P. (2014). Krajowy Program Rozwoju Ekonomii Społecznej wzmocni organizacje pozarzadowe?, http:// www.ekonomiaspoleczna.pl/wiadomosc/992281. html (dostęp: 09.04.2017).

Kaczorek Ł. (2012). Federacja nie chce Programu, http://www.ekonomiaspoleczna.pl/wiadomosc/803975.html (dostęp: 02.04.2017).

KPRES (2014). Krajowy Program Rozwoju Ekonomii Społecznej. Projekt z 24 lipca 2014 r. Warszawa: Ministerstwo Pracy i Polityki Społecznej.

KPRES przyjęty (2014). KPRES przyjęty przez rzad!, http://www.ekonomiaspoleczna.pl/wiadomosc/ 1001418.html (dostęp: 09.04.2017).

Krajowy (2014). Krajowy Program Rozwoju Ekonomii Społecznej na ostatniej prostej, http://www.ekonomiaspoleczna.pl/wiadomosc/979207.html (dostęp: 09.04.2017).

MPiPS (2014). Krajowy Program Rozwoju Ekonomii Społecznej skierowany na Komitet Stały Rady Ministrów, http://www.mpips.gov.pl/aktualnosci-wszystkie/ art,5533,6773,krajowy-program-rozwoju-ekonomiispolecznej-skierowany-na-komitet-staly-radyministrow.html (dostęp: 02.04.2017). dokumentem wyznaczającym cele rozwojowe i ma szansę przyczynić się do rozwoju ekonomii społecznej.
MRPiPS (2016). Pożyczki dla podmiotów ekonomii społecznej, https://www.mpips.gov.pl/aktualnosciwszystkie/ organizacjepozarzadowe/art,8486,pozyczkidla-podmiotow-ekonomii-spolecznej.html (dostęp: 28.05.2017).

Muzińska A. (2013). Krajowy Program Rozwoju Ekonomii Społecznej - co jeszcze można poprawić, http:// www.ekonomiaspoleczna.pl/wiadomosc/844258. html (dostęp: 09.04.2017).

Nowa (2013). Nowa wersja Krajowego Programu Rozwoju Ekonomii Społecznej, http://www.ekonomiaspoleczna.pl/wiadomosc/894347.html (dostęp: 02.04.2017).

Uchwała nr 1 Krajowego Komitetu Rozwoju Ekonomii Społecznej z dnia 4 października 2016 r. w sprawie Regulaminu Prac Komitetu, http:// www.pozytek.gov.pl/Krajowy,Komitet,Rozwoju,Ekonomii,Spolecznej,3941.html (dostęp: 09.04.2017).

Weihs W. (2012). Dolnoślaska Federacja także nie chce Programu KPRES, http://www.ekonomiaspoleczna.pl/wiadomosc/804890;jsessionid=FC98EDD980FB0CDF2CF67F8334EA8613.html?ci=es_komentarze\&did=\&state $=\mathrm{ml}$ (dostęp: 02.04.2017).

Wytyczne w zakresie realizacji przedsięwzięć w obszarze włączenia społecznego i zwalczania ubóstwazwykorzystaniemśrodkówEuropejskiego Funduszu Społecznego i Europejskiego Funduszu Rozwoju Regionalnego na lata 2014-2020, https://www.mr.gov.pl/strony/zadania/fundusze-europejskie/wytyczne/wytyczne-na-lata-2014-2020/ projekt-wytycznych-w-zakresie-realizacjiprzedsiewziec-w-obszarze-wlaczenia-spolecznegoi-zwalczania-ubostwa-z-wykorzystaniem-srodkowefs-i-efrr-na-lata-2014-2020/ (dostęp: 02.08.2017).

Zarządzenie nr 7 Ministra Pracy i Polityki Społecznej z dnia 27 lutego 2017 r. w sprawie powołania Krajowego Komitetu Rozwoju Ekonomii Społecznej, http://www.pozytek.gov.pl/ Krajowy,Komitet,Rozwoju,Ekonomii,Spolecznej,3941. html (dostęp: 09.04.2017).

\section{National Programme for Social Economy Development as a strategic document: Assumptions - content - reception}

Summary: The National Programme for Social Economy Development (KPRES) was adopted in 2014. It was supposed to become a determinant of directions of public intervention and contribute to the development of the social economy. The adopted framework has ensured the consistency of the activities carried out at all levels. This article discusses the process of establishing the KPRES, its assumptions, the role of the regions in its implementation and its reception in the environment. It is also an attempt to determine whether the Program as a strategic document has the potential to influence the development of the 
social economy. All of the measures envisaged in it are coherent, logically linked, and take into account the role of regions in development of social economy. However, on the basis of the discrepancy between it and other regional programs, it is noted that not all of its provisions are implemented, especially in the regions. While voivodships have updated regional social economy programs or set up regional committees, there have been problems with accrediting OWES or establishing the number of jobs to be created in PS. This shows that KPRES is probably not perceived as an important document outside the social economy.

Keywords: social economy, programme, jobs, KPRES.

\section{Prawa autorskie i licencja / Copyright and License}

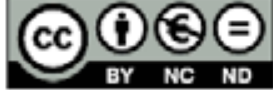

Artykuł opublikowano na licencji Creative Commons Uznanie autorstwa - Użycie niekomercyjne - Bez utworów zależnych 3.0 Polska http://creativecommons.org/licenses/by-nc-nd/3.0/pl/

This article is published under the terms of the Creative Commons Attribution - NonCommercial - NoDerivs (CC BY-NC-ND 3.0) License http://creativecommons.org/licenses/by-nc-nd/3.0/ 